\title{
POTENSI TEH HIJAU DALAM MENURUNKAN KADAR KOLESTEROL PADA AKSEPTOR KONTRASEPSI PROGESTIN HIPERKOLESTEROLEMIA
}

\section{The Potential Of Green Tea In Reducing Cholesterol Levels In Contraception Progestin Acceptors Hypercolesterolemia}

\author{
Vivi Maydawati ${ }^{1}$, Nora Veri ${ }^{* 2}$ \\ ${ }^{1}$ Puskesmas Sapta Jaya Aceh Tamiang \\ Desa Suka Mulia, Rantau, Aceh Tamiang Regency, Aceh 24453 \\ ${ }^{2}$ Prodi Kebidanan Langsa Poltekkes Kemenkes Aceh \\ Jl. Islamic Center Desa PB. Beuramoe Kec. Langsa Barat Kota Langsa, Indonesia \\ *Koresponding Penulis : nora.rahman1983@gmail.com
}

\begin{abstract}
ABSTRAK
Hasil Riskesdas tahun 2018 yang memperlihatkan bahwa prevalensi penyakit pembuluh darah seperti hipertensi yaitu sebesar $34.1 \%$ per 1000 penduduk. Salah satu penyebab hiperkolesterolemia adalah akibat metode kontrasepsi yang banyak digunakan yaitu KB hormonal yaitu sebesar (46.84\%). DMPA meningkatkan kadar kolesterol total salam darah. Salah satu cara mengatasi efek samping akibat penggunaan Depo Progestin adalah menggunakan teh hijau yang kaya akan antioksidan.

Rancangan penelitian adalah quasi eksperimen dengan pendekatan pretest posttest control group design. Jumlah sampel adalah 34 orang akseptor KB DMPA yang hiperkolesterolemia di wilayah kerja Puskesmas Sapta Jaya dan dibagi kedalam kelompok kontrol dan kelompok perlakuan teh hijau.

Hasil penelitian ini membuktikan bahwa terdapat perbedaan rerata kadar kolesterol antara kelompok kontrol dan perlakuan pada saat pretest dan posttest.

Kesimpulan teh hijau mampu menurunkan kadar kolesterol total pada ibu akseptor KB DMPA yang mengalami hiperkolesterolemia
\end{abstract}

Kata Kunci : DMPA, Kolesterol, Teh hijau

\begin{abstract}
The results of Riskesdas 2018 showed that the prevalence of blood vessel diseases such as hypertension was $34.1 \%$ of 1000 population. One of the causes of hypercholesterolemia is due to the widely used contraceptive method, hormonal birth control (46.84\%). DMPA increases total cholesterol levels in the blood. One way one way of coping with the side effects of using Depo Progestin is to use green tea which is rich in antioxidants.

The research design was a quasi-experimental study with a pretest-posttest control group design approach. The number of sample are 34 women of DMPA acceptors with hypercholesterolemia in the Sapta Jaya and divided into the control group and the green tea treatment group.

The results of this study prove that there are differences in the mean cholesterol levels between the control and treatment groups at the pretest and posttest.

Conclusion green tea is able to reduce total cholesterol levels in DMPA KB acceptor women who experience hypercholesterolemia
\end{abstract}

Keywords: DMPA, Cholesterol, Green Tea 
Journal of Healthcare Technology and Medicine Vol. 6 No. 2 Oktober 2020

Universitas Ubudiyah Indonesia

e-ISSN : 2615-109X

Beberapa studi epidemiologi pada sekurang-kurangnya empat belas negara menunjukkan bahwa hiperkolesterolemia termasuk dalam tiga faktor utama penyebab penyakit jantung koroner selain hipertensi dan kebiasaan merokok. Hiperkolesterolemia merupakan satu-satunya faktor resiko yang dengan sendirinya dapat menyebabkan atherosclerosis tanpa kombinasi dengan faktor lain (Hatma, 2011). Hasil Riskesdas tahun 2018 yang memperlihatkan bahwa prevalensi penyakit pembuluh darah seperti hipertensi yaitu sebesar $34.1 \%$ per 1000 penduduk (Kementerian Kesehatan RI Badan Penelitian dan Pengembangan, 2018). Salah satu penyebab hiperkolesterolemia adalah akibat metode kontrasepsi yang banyak digunakan yaitu KB hormonal yaitu sebesar (46.84\%). Jenis suntikan yang paling sering digunakan adalah Depo MedroxyprogesteronAcetat (DMPA) atau yang sering dikenal dengan Depo Progestin (Septalia \& Puspitasari, 2017). DMPA meningkatkan kadar kolesterol total salam darah (Susilawati et al., 2015). Wanita pengguna Depo Progestin lebih beresiko mengalami peningkatan berat badan, yang diakibatkan oleh akumulasi lemak terutama lemak viseral. Hal ini terjadi karena tubuh mengalami penurunan kadar esterogen dan perubahan hormon leptin yang berfungsi pengatur nafsu makan yang pada akhirnya memicu obesitas (Wahyuni et al., 2016). Salah satu cara mengatasi efek samping akibat penggunaan Depo Progestin adalah menggunakan teh hijau (camellia sinensis). Polifenol teh (katekin dan theaflavin) juga merupakan antioksidan kuat yang mampu melindungi oksidasi LDL kolesterol oleh radikal bebas (Rahayu et al., 2015). Banyak penelitian menyatakan terdapat perbedaan yang signifikan kadar kolesterol antara kelompok perlakuan dan kelompok kontrol setelah pemberian teh hijau (Fajria Maulida \& Sri Wahyuni, 2018; Sriyono \& Proboningsih, 2012). Teh hijau mampu menurunkan stress oksidatif pada organ reproduksi, vaskular, akibat penggunaan DMPA (Emilda et al., 2017; Veri et al., 2015, 2019).

\section{METODE PENELITIAN}

Rancangan penelitian adalah quasi eksperimen dengan pendekatan pretest posttest control group design yaitu pengumpulan data dilakukan sebelum dan sesudah perlakuan (Latuconsina, 2018). Pada pengujian data pretest dilakukan 1 hari sebelum diberikan perlakuan selanjutnya dilakukan pemberian teh hijau pada kelompok intervensi selama 14 hari berturut - turut, pada hari ke 15 dilakukan posttest pengumpulan data dengan melihat kadar kolesterol total pada akseptor KB DMPA diwilayah kerja UPTD Puskesmas Sapta Jaya Kabupaten Aceh Tamiang tahun 2019 yang melibatkan 2 kelompok (kontrol dan perlakuan pemberian teh hijau dosis 2,4 gr/hari). Pengukuran kadar kolesterol total menggunakan metode Endpoint pada serum darah vena dengan menggunakan alat Mindray Bs-120 yang dilakukan di laboratorium Puskesmas Sapta Jaya. Populasi dalam penelitian ini adalah seluruh akseptor KB DMPA yang mengalami hiperkolesterol di wilayah kerja UPTD Puskesmas Sapta Jaya Kabupaten Aceh Tamiang.

\section{HASIL PENELITIAN DAN PEMBAHASAN}

1. Data Univariat

Hasil olah data univariat seperti yang terlihat pada tabel berikut ini :

Tabel 1

Karakteristik Akseptor KB DMPA hiperkolesterolemia 
Journal of Healthcare Technology and Medicine Vol. 6 No. 2 Oktober 2020

Universitas Ubudiyah Indonesia

e-ISSN : 2615-109X

\begin{tabular}{|c|c|c|}
\hline Karakteristik & $\mathbf{F}$ & $\%$ \\
\hline \multicolumn{3}{|l|}{ Usia } \\
\hline 26-30 tahun & 5 & 14.7 \\
\hline 31-35 tahun & 13 & 38.2 \\
\hline 36-40 tahun & 16 & 47.1 \\
\hline Total & 34 & 100 \\
\hline \multicolumn{3}{|l|}{ Pekerjaan } \\
\hline Pegawai Negeri Sipil (PNS) & 4 & 11.8 \\
\hline Non Pegawai Negeri Sipil (PNS) & 5 & 14.7 \\
\hline Tidak Bekerja & 25 & 73.5 \\
\hline Total & 34 & 100 \\
\hline \multicolumn{3}{|l|}{ Lamanya Pemakaian DMPA } \\
\hline 1.5 tahun & 5 & 14.7 \\
\hline 2.5 tahun & 13 & 38.2 \\
\hline 3 tahun & 16 & 47.1 \\
\hline Total & 34 & 100 \\
\hline
\end{tabular}

Berdasarkan tabel diatas menunjukkan bahwa mayoritas responden berada dalam rentang usia 36-40 tahun yakni sebesar $47.1 \%$. Sedangkan berdasarkan pekerjaan mayoritas responden adalah tidak bekerja yakni sebesar $73.5 \%$ dan berdasarkan lamanya pemakaian DMPA bahwa mayoritas responden menjadi akseptor KB DMPA selama 3 tahun yakni sebesar $47.1 \%$.

2. Data Bivariat

Data bivariat diolah dengan menggunakan uji parametrik

Tabel

Pengaruh Teh Hijau Terhadap Kadar Kolesterol Pada Akseptor KB DMPA Hiperkolesterolemia

\begin{tabular}{ccc}
\hline \multirow{2}{*}{ Variabel } & \multicolumn{2}{c}{ Kelompok } \\
\cline { 2 - 3 } & Kontrol & Teh Hijau \\
Kadar kolesterol (mg/dl) Pretest & $228.00 \pm 18.921$ & $231.33 \pm 6.501$ \\
Kadar kolesterol (mg/dl) Postest & $215.67 \pm 11.501$ & $179.00 \pm 6.099 *$ \\
\hline
\end{tabular}

Catatan:

Nilai yang ditampilkan adalah nilai rerata \pm standar deviasi

$* p<0.05$ jika dibandingkan dengan data pretest

Tabel diatas menunjukkan gambaran perbedaan rerata kadar kolesterol total pada kelompok kontrol dan perlakuan. Rerata kadar kolesterol total yang terendah terdapat pada kelompok the hijau yaitu $179.00 \mathrm{mg} / \mathrm{dl} \mathrm{dan}$ tertinggi pada kelompok kontrol yaitu $231.33 \mathrm{mg} / \mathrm{dl}$. Hasil penelitian ini membuktikan bahwa terdapat pengaruh teh hijau dalam menurunkan kadar kolesterol total. Penelitian ini sejalan dengan penelitian sebelumnya yang menyebutkan bahwa ada pengaruh pemberian teh hijau terhadap penurunan kadar kolesterol pada lansia (Sriyono 
Journal of Healthcare Technology and Medicine Vol. 6 No. 2 Oktober 2020

Universitas Ubudiyah Indonesia

e-ISSN : 2615-109X

\& Proboningsih, 2012). Hal ini dukung pula oleh penelitian (Rahmadani et al., 2015) yang menyebutkan bahwa pemberian ekstrak teh hijau mampu menurunkan kadar kolesterol total. Ekstrak teh hijau juga berpengaruh menurunkan kadar leptin pada tikus putih yand dipapar Depo Progestin (Wahyuni \& Putri, 2017).

Pengaruh penggunaan jangka panjang dari DMPA yang telah menggunakan lebih dari 2 tahun menunjukkan bahwa kadar trigliserida, kolesterol total dan Low Density Lipoprotein (LDL) lebih tinggi sedangkan kadar High Density Lipoprotein (HDL) (Yadav et al., 2011). Hal ini diduga dikarenakan Progesteron yang terkandung dalam kontrasepsi dapat mempengaruhi kerja Hepatic Lipase (HL). Hepatic Lipase (HL) merupakan enzim yang membantu proses sekresi dari HDL - kolesterol, apabila kerja HL terhambat maka produksi HDL mengalami penurunan dan LDL mengalami peningkatan serta terjadi peningkatan pada trigliserida (Annema \& Tietge, 2011). Kandungan Flavonoid pada teh hijau telah terbukti dapat memperbaiki profil lipid darah dan memiliki efek vasoprotektif juga memiliki kemampuan untuk menghambat CETP (Cholesteryl Ester Transfer Protein), sehingga dapat meningkatkan kadar kolesterol HDL dan menurunkan kadar kolesterol LDL (Pereira et al., 2014). Flavonoid juga memiliki efek anti inflamasi dengan cara menghambat sitokin seperti tumor necrosis factor $\alpha$ (TNF- $\alpha$ ). Penurunan TNF- $\alpha$ akan meningkatkan sensitivitas insulin, meningkatkan oksidasi asam lemak di hepar, dan menghambat sintesis kolesterol oleh sel hepar (Hardani et al., 2014).

Kemampuan teh hijau dalam menurunkan kolesterol adalah disuga juga berhubungan kandungan saponin didalamnya. Saponin yang memiliki efek antihiperlipidemia, yaitu dengan menghambat kerja 3-Hydroxy-3methylglutaryl CoA reductase (HMGCR) dan Acyl-CoA: cholesterol O-acyltransferase 2 (ACAT2). HMGCR adalah enzim yang meregulasi biosintesis kolesterol. Selain itu saponin meningkatkan ekspresi cholesterol 7alpha-hydroxylase (CYP7A1) yang merupakan enzim yang terlibat dalam jalur biosintesis asam empedu dan terlibat dalam 75\% dari proses produksi asam empedu. Peningkatan ekspresi maupun aktivitas dari enzim CYP7A1 akan meningkatkan jalur katabolik kolesterol dan menyebabkan pengurangan kadar kolesterol total dalam serum dan hati (Tsujii et al., 2010).

Teh hijau juga mempunyai kandungan polifenol yang tinggi. Polifenol teh (katekin dan theaflavin) merupakan antioksidan kuat yang mampu melindungi oksidasi kolesterol oleh radikal bebas. Polyphenol yang terkandung dalam teh hijau sebagai antioksidan membantu kerja enzim superoxide dismulate (SOD) akibat paparan DMPA (Veri et al., 2015). Hiperkolesterolemia menyebabkan menurunnya kandungan antioksidan SOD pada jaringan hati sehingga dibutuhkan antioksidan kuat untuk mencegah terjadinya stress oksidatif (Wresdiyati et al., 2006)

\section{KESIMPULAN}

Teh hijau mampu menurunkan kadar kolesterol yang diakibatkan oleh pemakaian DMPA pada akseptor KB DMPA hiperkolesterolemia

\section{SARAN}

Penelitian lanjutan dapat dilakukan dengan memperhatikan waktu pemberian, pengendalian faktor pengganggu, dan membandingkan teh hijau dengan tanaman herbal lain. 
Journal of Healthcare Technology and Medicine Vol. 6 No. 2 Oktober 2020

Universitas Ubudiyah Indonesia

e-ISSN : 2615-109X

\section{UCAPAN TERIMAKASIH}

Terimakasih penulis ucapkan kepada Puskesmas Sapta Jaya dan Prodi Kebidanan Langsa yang telah memfasilitasi penelitian dan penulisan manuskrip ini

\section{REFERENSI}

Annema, W., \& Tietge, U. J. F. (2011). Role of hepatic lipase and endothelial lipase in high-density lipoproteinmediated reverse cholesterol transport. In Current Atherosclerosis Reports. https://doi.org/10.1007/s11883011-0175-2

Emilda, A. S., Veri, N., \& Alchalidi, A. (2017). High dose of green tea infusion normalized spiral artery density in rats treated with the depot-medroxyprogesterone acetate. Journal of Intercultural Ethnopharmacology. https://doi.org/10.5455/jice.20160928012442

Fajria Maulida, L., \& Sri Wahyuni, E. (2018). Upaya Menurunkan Radikal Bebas Dengan Ekstrak Bunga Cempaka Pada Tikus Model Menopause. Gaster | Jurnal Ilmu Kesehatan, 16(1), 6. https://doi.org/10.30787/gaster.v16i1.238

Hardani, E., Lestariana, W., \& Susetyowati, S. (2014). Efek pemberian ekstrak teh hijau (Camellia sinesis (L) O. Kuntze) var. Assamica terhadap total lemak tubuh dan profil lipid wanita dewasa overweight dan obesitas. Jurnal Gizi Klinik Indonesia. https://doi.org/10.22146/ijcn.18874

Hatma, R. D. (2011). Lipid profiles among diverse ethnic groups in Indonesia. Acta Medica Indonesiana.

Kementerian Kesehatan RI Badan Penelitian dan Pengembangan. (2018). Hasil Utama Riset Kesehatan Dasar. Kementrian Kesehatan Republik Indonesia.

Latuconsina, N. D. (2018). Penelitian Eksperimen. Metode Penelitian Kesehatan.

Pereira, V. ., Knor, F. ., Vellosa, J. C. ., \& Beltrame, F. . (2014). Determination of phenolic compounds and antioxidant activity of green, black and white teas of Camellia sinensis (L.) Kuntze, Theaceae. Revista Brasileira de Plantas Medicinais. https://doi.org/10.1590/1983-084x/13_061

Rahayu, F., Jose, C., \& Haryani, Y. (2015). Total Fenolik, Flavonoid, dan Aktivitas Antioksidan Dari Produk Teh Hijau dan Teh Hitam Tanaman Bangun-Bangun (Coleus Amboinicus) dengan Perlakuan Ett Rumput Paitan. Jom Fmipa.

Rahmadani, R., Nugroho, R. A., \& Sudiastuti. (2015). Pengaruh Teh Hijau (Camelia sinensis) dan Teh Apel (sylvestris mill) Komersial Terhadap Penurunan Indeks Obesitas dan profil lipid Mencit (mus musculus L.)yang telah Obesitas. Prosiding Seminar Tugas Akhir FMIPA UNMUL.

Septalia, R., \& Puspitasari, N. (2017). Faktor yang Memengaruhi Pemilihan Metode Kontrasepsi. Jurnal Biometrika Dan Kependudukan, 5(2), 91. https://doi.org/10.20473/jbk.v5i2.2016.91-98

Sriyono, \& Proboningsih, J. (2012). PENGARUH PEMBERIAN TEH HIJAU TERHADAP TEKANAN DARAH DAN KADAR KOLESTEROL (LDL) PADA LANSIA DENGAN HIPERTENSI. Jurnal Keperawatan Soedirman.

Susilawati, E., Barlianto, W., \& Wayan Arsana Wiyasa, I. (2015). Cholesterol/HDL-c ratio lowering effect of green tea in rats exposed to depot medroxiprogesterone acetate. Journal of Experimental and Integrative Medicine. https://doi.org/10.5455/jeim.140915.br.025

Tsujii, H., Afrose, S., Hossain, M. S., Salma, U., \& Miah, A. G. (2010). Dietary karaya saponin and rhodobacter capsulatus exert hypocholesterolemic effects by suppression of hepatic cholesterol synthesis and promotion 
of bile acid synthesis in laying hens. Cholesterol. https://doi.org/10.1155/2010/272731

Veri, N., AS, E., Mutiah, C., Seriana, I., \& Malinda, R. (2019). Protective effect of green tea on tunica adventitia and endothelial changes resulting from depot medroxy progesterone acetate. Journal of Taibah University Medical Sciences. https://doi.org/10.1016/j.jtumed.2018.10.002

Veri, N., Aulia, F., Ratnawati, R., Hidayati, D. Y. N., Noorhamdani, N., \& Dwijayasa, P. M. (2015). Protective effect of green tea against ovarian and endometrial apoptoses in rats treated with depot medroxyprogesterone acetate. Biomarkers and Genomic Medicine. https://doi.org/10.1016/j.bgm.2015.04.002

Wahyuni, E. S., \& Putri, A. K. (2017). Upaya Mencegah Efek Samping Penggunaan Kontrasepsi Depo Progestin Dengan Ekstra Teh Hijau. XV(1), 87-97.

Wahyuni, E. S., Wiyasa, I. W. A., \& Nurdiana, N. (2016). Combined high dose vitamin C and E increases oxidative stress and visceral fat mass in rats treated by depot-medroxyprogesterone acetate. Middle East Fertility Society Journal. https://doi.org/10.1016/j.mefs.2016.06.001

WRESDIYATI, T. U. T. I. K., ASTAWAN, M. A. D. E., \& HASTANTI, L. Y. (2006). Profil Imunohistokimia Superoksida Dismutase (SOD) pada Jaringan Hati Tikus dengan Kondisi Hiperkolesterolemia. HAYATI Journal of Biosciences, 13(3), 85-89. https://doi.org/10.1016/S1978-3019(16)30298-4

Yadav, B. K., Gupta, R. K., Gyawali, P., Shrestha, R., Poudel, B., Sigdel, M., \& Jha, B. (2011). Effects of longterm use of depo-medroxyprogesterone acetate on lipid metabolism in nepalese women. Korean Journal of Laboratory Medicine. https://doi.org/10.3343/kjlm.2011.31.2.95 